\title{
Liver transplantation in the treatment of ornithine transcarbamylase deficiency
}

\author{
Jingya Wei, Bo Hui \\ Department of Neurology, Xijing Hospital, Fourth Military Medical University, Xian, China \\ Dr. Jingya Wei, Department of Neurology, Xijing Hospital, \\ Phone: +86298477 1055 \\ Fourth Military Medical University, 15 Changle-xi Road, \\ E-mail: iamtrn@126.com \\ Xian 710032, Shaanxi province, China
}

Citation: Wei J, Hui B. Liver transplantation in the treatment of ornithine transcarbamylase deficiency. Cell Ther Transplant 2021; 10(3-4): 26-29.

\section{Summary}

Ornithine transcarbamylase deficiency (OTCD) is a genetic disorder causing disturbed urea metabolic cycle with a high mortality rates. It's a genetic metabolic disease manifesting as hyperammonemia. Drugs and hemodialysis may reduce blood ammonia levels in the patients. Liver transplantation may improve the long-term survival rate of patients, but it cannot reverse the nervous system damage that has occurred before, and cannot improve cognition. If the liver transplant is performed early in childhood, neurodevelopment may be normal at later terms. Late-onset patients should also be transplanted when required. Heterozygosity for OTCD in the donor is still risky and should only be used when there are no other options. Hepatocyte transplantation can be tried if necessary. Prevention of infection, long-term monitoring of liver function and blood ammonia are required posttransplant. Liver transplantation should be considered for all patients with genetic OTCD. The final decision of whether and how to use this treatment mode depends on individual clinical circumstances.

\section{Keywords}

Ornithine transcarbamylase deficiency, urea cycle disorder, liver transplantation, hepatocyte transplantation.

\section{Introduction}

Ornithine transcarbamylase deficiency (OTCD) is an $\mathrm{X}$-linked genetic urea cycle disorder (UCD) caused by the mutation of the ornithine transcarbamylase (OTC, Xp2.1) gene. OTC is a mitochondrial enzyme synthesized in the cytoplasm. Following OTC transfer to the mitochondria, carbamoyl phosphate and ornithine are catalytically converted to citrulline. Then citrulline is transported to the cytoplasm to participate in the urea cycle reactions. The OTC gene mutations block normal urea metabolism. Therefore, increased blood ammonia, decreased blood citrulline and increased urine orotic acid are typical biochemical phenotypes of OTCD. High blood ammonia could cause the nervous system damage, epilepsy-like symptoms, disturbed consciousness, and cognitive impairment appear.

Early-onset OTCD mainly occurs in male heterozygous infants, usually with a rapid onset and a high mortality in the neonatal period [1]. The patient can be normal at birth. Then irritability, deteriorating feeding, drowsiness and tachypnea appear soon. It often develops into metabolic encephalopathy rapidly and leads to death if treatment is not applied. Severe intellectual impairment will be left in survivors due to the extensive damage to the brain caused by elevated blood ammonia [2]. Late-onset OTCD can occur in hemizygous males and heterozygous females. The clinical symptoms are variable and mild compared with early-onset OTCD.

The main principle of treatment is to control diet, reduce protein intake, avoid hyperammonemia, and use drugs to promote blood ammonia metabolism. However, excessive restriction of protein intake can lead to hypertrophy of endogenous protein catabolism, increase blood ammonia, and affect the patient's intelligence and physical development [3]. If the drug treatment is not effective, dialysis treatment should be considered as soon as possible.

Liver transplantation (LTx) is the most effective treatment of this disease, since OTC activity is mainly expressed in liver tissue. In these cases, the patients can stop anti-hyperammonemia drugs and return to normal diet after LTx. Hyperammonemia will not occur again, and the quality of life 
is significantly improved $[4,5]$. Though LTx can correct the patient's urea cycle disorder and reduce blood ammonia substantially, it cannot reverse the nervous system damage that has occurred before LTx [5].

\section{Indications for surgery}

For the neonatal-onset patients, LTx should be performed as soon as possible if the patient's condition is stable, independently on the blood ammonia levels. Considering the patient's tolerance for surgery and the risk of post-transplant hyperammonemia, the age of 3 months to 1 year, or body mass of $>5 \mathrm{~kg}$ are appropriate pre-requisites for surgery [3]. It is usually done at six months of age. Early transplantation in the neonatal-onset patients may be associated with normal neurodevelopment compared with those without LTx.

For late-onset patients, it is now generally believed that, even with mild current manifestations, there is a risk of sudden, potentially life-threatening hyperammonemia at any age. Therefore, surgery should be considered for any OTCD patient. Final decision of LTx depends on the individual circumstances.

The peak of death with OTCD is noted at the age of 12-15 years in female patients, thus considering LTx before that time [6]. LTx in adolescents may also promote normal neurodevelopment. The patients should undergo LTx at peak blood ammonia levels of $>300 \mu \mathrm{mol} / \mathrm{L}$ [7]. In cases of severe progressive liver disease, repeated metabolic abnormalities after standard treatment or poor compliance with current treatment, LTx can be also performed [3].

Analysis of data on the patients under 18 year subjected to LTx between February 2002 and September 2020, the waiting list time and male sex were associated with long-term risk for a cognitive delay. Minimizing the waiting time is quite important, in order to maintain the patient's cognition capacities at later terms and improve the quality of life [8].

All the patients with OTCD should be considered for LTx to prevent progressive neurological injury. But the decision is usually taken in cases of unstable condition and frequent episodes of hyperammonemia.

\section{Donor selection}

Liver transplants from either living or deceased donors are acceptable for the children of 1.5 to 3.0 years old. Three patients received cadaveric LTx at this age period. They developed well after this operation, and no recurrences were observed within follow-up for 13 years [9].

LTx from living donors is the most effective method in these cases. Living donors for the LTx should be in healthy condition, but sometimes there is no time to wait for another donor, except for subjects heterozygous for the mutated gene. A symptom-free carrier may be a donor for LTx, if OTC enzyme activity is high enough, and if no other options exist. The mutation carrier must undergo careful and comprehensive examination. OTC activity in liver biopsy samples must be tested to determine the suitability of heterozygote to be a donor [10]. According to Wakiya, T, the OTC activity of late-onset patients requiring LTx, ranges from $4.4 \%$ to $18.7 \%$. Meanwhile, in those cases where LTx is not necessary, the residual enzyme activity ranges from $33 \%$ to $38 \%$ [11]. Rahayatri et al. [12] reported two 5-year-old girls who received liver transplants from heterozygous mutation carriers. The OTC activity in the first case and in her donor was $15 \%$ and $62 \%$, respectively. She developed hyperammonemia within 2 months after the surgery. OTC activity in the second case and the donor was $9.7 \%$ and $42.6 \%$, respectively. She developed hyperammonemia within 12 days after the surgery. Following continuous intravenous/venous hemodialysis, they were performing well without intensive care [12].

However, this method has potential risks. The enzyme activity in selected biopsy samples cannot represent its activity in other parts of the liver. Hence, one cannot accurately predict, whether the transplanted liver lobe exhibits sufficient activity, nor to predict whether total enzyme activity retained in the left liver is sufficient for heterozygous carrier donors.

Transplantation of hepatocytes may be another treatment option. Enosawa et al. reported an 11-day-old baby who underwent hepatocyte transplantation. The patient needed urgent LTx, but there was no source of liver, thus requiring hepatocyte transplantation. The patient was later in good condition and without recurrence within 3 months after the operation [13]. For the patients with poor overall clinical conditions, hepatocyte transplantation is less risky than liver grafting. Following hepatocyte transplantation, biochemical parameters of a 12-year-old patient with repeated metabolic decompensation showed decreased levels of plasma ammonia and increased urea production. However, the patient died because of a nosocomial fungal sepsis [14].

\section{Surgical methods}

Orthotopic LTx is still the best choice in OTCD. It has fewer complications than auxiliary LTx [5]. Over recent years, a domino cross-auxiliary LTx has been tried in the clinical setting. This method is based on exchanging part of liver tissue with patients suffering from other metabolic diseases aiming to achieve metabolic complementation. It does not require additional organ donation. Of the three OTCD patients in China, subjected to domino cross-auxiliary LTx, two cases recovered well after the operation, without any complications during the follow-up period. One patient experienced occult graft rejection resulting into graft dysfunction and eventual disease recurrence [15]. The domino cross-auxiliary LTx is a feasible method, without any problems caused by the operation itself.

\section{Post-transplant management}

Due to long-term therapy with immunosuppressive drugs and postoperative weakness, one should notice prevention of postsurgical infections, which may cause failure of this intervention and death of the patient.

Following transplantation, the liver function should be tested regularly, to discern graft injury. The graft-derived cellfree DNA in blood may be of similar discriminative value, 
it was also able to differentiate between the trend for graft injury and normal liver function. However, this technique is not as convenient as routine liver function tests [16]. The peak blood ammonia level of $>356 \mu \mathrm{mol} / \mathrm{L}$ predicted poor neurodevelopmental outcomes in the patients undergoing LTx [17].

\section{Clinical effect}

According to the data from United Network for Organ Sharing (UNOS) database including 403 patients with urea cycle disorders (46.2\% were OTCD) who underwent transplantation, the 1-, 3-, and 5-year graft survival rates were $90.4 \%$, $86.3 \%$, and $85.2 \%$, respectively. Increased mass of the liver graft and male sex are related to decreased risk of graft loss [8]. In Japan, the 1-, 5-, 10-, and 15-year graft survival rates comprised $91.2 \%, 87.9 \%, 87.0 \%$, and $79.3 \%$ among pediatric patients with metabolic disorders (OTCD, 20.6\% of total) as shown by Kasahara et al. [18].

The 1-, 5-, and 10-year overall survival rates among 278 UCD patients who underwent LTx between 1987 and 2010 were $93 \%, 89 \%$, and $87 \%$, respectively, according to the UNOS database [19]. However, the article only stated that most UCD patients are OTCD, without any specific data on OTCD patients.

13 of 69 Chinese OTCD patients received LTx, at a median age of 3 years and one-year survival rate of 100\% [20]. In Japan, the 1-, 5-, 10- and 15-year survival rates in 194 pediatric patients with metabolic disorders $(\mathrm{OTCD}=40)$ who underwent living donor LTx, were $91.2 \%, 87.9 \%, 86.1 \%$, and $74.4 \%$ [18].

Hence, LTx can improve long-term survival rates of the patients, prevent recurrent hyperammonemia, and reduce the blood ammonia level. However, it did not improve neurodevelopmental outcomes in the patients with severe symptomatics, because hyperammonemia exerts early brain damage. Urgent LTx in another UCD, i.e., arginine succinate synthase deficiency, may improve the longitudinal cognitive and behavioural outcomes [17].

\section{Conclusions}

LTx can improve the long-term survival rate of patients with OTCD, but it cannot reverse the nervous system damage that occurred previously, and cannot improve cognitive impairment. However, neurodevelopment may normally proceed after LTx if it is performed early in childhood. The patients with late-onset disease should also be transplanted when required. Donorship of heterozygote carriers is still risky and should only be used when there are no other options. Hepatocyte transplantation can be tried if necessary. Prevention of infection, long-term monitoring of liver function and blood ammonia are required post-transplant.

\section{Conflict of interest}

The authors declare that they have no conflicts of interest.

\section{References}

1. Summar ML, Dobbelaere D, Brusilow S, Lee B. Diagnosis, symptoms, frequency and mortality of 260 patients with urea cycle disorders from a 21-year, multicentre study of acute hyperammonaemic episodes. Acta Paediatr. 2008; 97(10):1420-1425. doi: 10.1111/j.1651-2227.2008.00952.x

2. Msall M, Batshaw ML, Suss R, Brusilow SW, Mellits ED. Neurologic outcome in children with inborn errors of urea synthesis. Outcome of urea-cycle enzymopathies. $\mathrm{N}$ Engl J Med. 1984; 310(23):1500-1505. doi: 10.1056/ NEJM198406073102304

3. Haberle J, Burlina A, Chakrapani A, Dixon M, Karall D, Lindner M, et al. Suggested guidelines for the diagnosis and management of urea cycle disorders: First revision. J Inherit Metab Dis. 2019; 42(6): 1192-1230. doi: 10.1002/jimd.12100

4. Kim IK, Niemi AK, Krueger C, Bonham CA, Concepcion W, Cowan TM, et al. Liver transplantation for urea cycle disorders in pediatric patients: a single-center experience. Pediatr Transplant. 2013; 17(2): 158-167. doi: 10.1111/petr.12041

5. Morioka D, Kasahara M, Takada Y, Shirouzu Y, Taira K, Sakamoto S, et al. Current role of liver transplantation for the treatment of urea cycle disorders: a review of the worldwide English literature and 13 cases at Kyoto University. Liver Transpl. 2005; 11(11):1332-1342. doi: 10.1002/lt.20587

6. Division of Genetics and Metabolism, Child Diseases and Health Care Branch, Chinese Association for Maternal and Child Health. Consensus on diagnosis and treatment of ornithine trans-carbamylase deficiency, J Zhejiang Univ (Med Sci), 2020; 49(5):539-547 (In Chinese). doi: 10.3785/j. issn.1008-9292.2020.04.11

7. Kido J, Matsumoto S, Mitsubuchi H, Endo F, Nakamura $\mathrm{K}$. Early liver transplantation in neonatal-onset and moderate urea cycle disorders may lead to normal neurodevelopment. Metab Brain Dis. 2018; 33(5): 1517-1523. doi: 10.1007/ s11011-018-0259-6

8. Ziogas IA, Wu WK, Matsuoka LK, Pai AK, Hafberg ET, Gillis LA, et al. Liver transplantation in children with urea cycle disorders: the importance of minimizing waiting time. Liver Transpl. 2021, May 31. doi: 10.1002/lt.26186

9. Zhu Z, Sun L, Wei L, et al. Liver transplantation for the treatment of hyperammonemia due to urea cycle disorder: report of four cases. Zhonghua Er Ke Za Zhi (Chinese Journal of Pediatrics). 2015; 53(2): 136-139 (In Chinese). doi: $10.1159 / 000416533$

10. Wakiya T, Sanada Y, Urahashi T, Ihara Y, Yamada N, Okada $\mathrm{N}$, et al. Living donor liver transplantation from an asymptomatic mother who was a carrier for ornithine transcarbamylase deficiency. Pediatr Transplant. 2012; 16(6):E196-200. doi: 10.1111/j.1399-3046.2012.01716.x

11. Wakiya T, Sanada Y, Urahashi T, Ihara Y, Yamada N, Okada $\mathrm{N}$, et al. Impact of enzyme activity assay on indication in liver transplantation for ornithine transcarbamylase deficiency. Mol Genet Metab. 2012; 105(3): 404-407. doi: 10.1016/j.ymgme.2011.12.019 
12. Rahayatri TH, Uchida H, Sasaki K, Shigeta T, Hirata $Y$, Kanazawa $\mathrm{H}$, et al. Hyperammonemia in ornithine transcarbamylase-deficient recipients following living donor liver transplantation from heterozygous carrier donors. Pediatr Transplant. 2017; 21(1). doi: 10.1111/petr.12848

13. Enosawa S, Horikawa R, Yamamoto A, Sakamoto S, Shigeta T, Nosaka S, et al., Hepatocyte transplantation using a living donor reduced graft in a baby with ornithine transcarbamylase deficiency: a novel source of hepatocytes. Liver Transpl. 2014; 20(3): 391-393. doi: 10.1002/lt.23800

14. Ribes-Koninckx C, Ibars ER, Calzado Agrasot MA, Bonora-Centelles A, Miquel BP, Vila Carbó JJ, et al. Clinical outcome of hepatocyte transplantation in four pediatric patients with inherited metabolic diseases. Cell Transplant. 2012; 21(10): 2267-2282. doi: 10.3727/096368912X637505

15. Qu W, Wei L, Zhu ZJ, Sun LY, Liu Y, Zeng ZG. Considerations for use of domino cross-auxiliary liver transplantation in metabolic liver diseases: A review of case studies. Transplantation. 2019; 103(9):1916-1920. doi: 10.1097/ $\underline{\text { TP.0000000000002602 }}$

16. Ng HI, Sun LY, Zhu ZJ. Application of graft-derived cellfree DNA in ornithine transcarbamylase deficiency patient after living donor liver transplantation: Two case reports. Medicine (Baltimore). 2018; 97(51): e13843. doi: 10.1097/ MD.0000000000013843
17. Kido J, Matsumoto S, Haberle J, Inomata Y, Kasahara M, Sakamoto S, et al. Role of liver transplantation in urea cycle disorders: Report from a nationwide study in Japan. J Inherit Metab Dis. 2021. doi: 10.1002/jimd.12415

18. Kasahara M, Sakamoto S, Horikawa R, Koji U, Mizuta $\mathrm{K}$, Shinkai $\mathrm{M}$, et al. Living donor liver transplantation for pediatric patients with metabolic disorders: the Japanese multicenter registry. Pediatr Transplant. 2014; 18(1): 6-15. doi: $10.1111 /$ petr.12196

19. Yu L, Rayhill SC, Hsu EK, Landis CS. Liver transplantation for urea cycle disorders: analysis of the united network for organ sharing database. Transplant Proc. 2015; 47(8): 2413-2418. doi: 10.1016/j.transproceed.2015.09.020

20. Lu D, Han F, Qiu W, Zhang H, Ye J, Liang L, et al. Clinical and molecular characteristics of 69 Chinese patients with ornithine transcarbamylase deficiency. Orphanet J Rare Dis. 2020; 15(1): 340. doi: 10.1186/s13023-020-01606-2

\section{| Трансплантация печени при лечении дефицита орнитин-транскарбамилазы}

\section{Джингуа Вэй, Бо Хюи}

Департамент неврологии, Госпиталь Сиджин, 4-й Военно-Медицинский университет, Сиань, Китай

\section{Резюме}

Дефицит орнитин-транскарбамилазы (ДОТК) представляет собой наследственное заболевание с нарушением цикла обмена мочевины, характеризующееся высокой летальностью. Это генетическое нарушение обмена веществ проявляется гипераммониемией. Лекарства и гемодиализ могут снизить уровень аммиака в крови у пациентов. Трансплантация печени может улучшить долгосрочную выживаемость пациентов, но не может излечить необратимые повреждения нервной системы, возникшие ранее, и не может улучшить когнитивные функции. Если трансплантацию печени проводят в раннем детстве, впоследствии нервное развитие может быть нормальным. При необходимости пациентам с поздним дебютом также следует проводить трансплантацию. Гетерозиготность по ДОТК у донора все же представляет существенный риск, и ее следует использовать только тогда, когда нет других вариантов. При необходимости можно попытаться сделать трансплантацию гепатоцитов. После трансплантации необходима профилактика инфекции, длительный контроль функции печени и содержания аммиака в крови. Трансплантация печени должна рассматриваться для всех пациентов с генетическим ДОТК. Окончательное решение о том, следует ли и как использовать этот режим лечения, зависит от индивидуальной клинической ситуации.

\section{Ключевые слова}

Дефицит орнитин-транскарбамилазы, нарушение цикла мочевины, трансплантация печени. 